\title{
THE LEGAL AND CONSTITUTIONAL FRAMEWORK OF THE 2011 ELECTIONS IN NIGERIA
}

\section{Dauda Abubakar}

\author{
Dr Abubakar is Assistant Professor in the Department of African Studies \& \\ Political Science, University of Michigan-Flint \\ email: dauda@umflint.edu
}

\begin{abstract}
The electoral topography of the Nigerian postcolonial state reveals that contests for the control of power degenerate more often than not into elitedriven violence that undermines the nation-building and democratic projects. In interrogating the legal and constitutional context and the outcome of the 2011 election in Nigeria this paper draws on Foucault's notion of governmentality, along with the concept of garrison politics, to unpack the central role that techniques, practices and strategies of governmental power play in the domination of the social, economic and political space, to the detriment of the citizenry. I argue that although the 2011 election was regarded as relatively 'free and fair' its aftermath, nevertheless, reveals the way centralisation of power is recurrently deployed through neopatrimonial networks to entrench elite pillage, which undermines the ethos of participatory democracy and constitutionalism. I contend that in order to avert corrosive decline and civic disengagement it is imperative to rethink and urgently reconstitute the institutional logic of the Nigerian state in such a manner that it will enhance the empowerment of the citizenry and the enthronement of a transparent, inclusive, developmentalist and responsive system of governance.
\end{abstract}

\section{INTRODUCTION}

Since Nigeria's inception as an independent political entity in 1960 elections in the country have, more often than not, been characterised by thuggery, rigging, violence, intimidation of opponents and the destruction of human lives and property. At national, regional and local levels elections have been dominated by the winner-takes-all syndrome, making politicians take all necessary measures to ensure that they do not lose out. 
A closely related factor, which exacerbates political violence in Nigeria's electoral process, is the nature, logic and character of the post-colonial state. Unlike the situation in advanced democratic polities, where institutions of accountability and the rule of law are relatively entrenched in the political culture, in post-colonial states like Nigeria institutions of accountability and state apparatuses of power are flagrantly appropriated by the dominant elite to serve neo-patrimonial and clientelist interests rather than the broader public good.

Furthermore, since the state itself remains the primary source of wealth generation and rent seeking, the struggle to monopolise is usually contentious and violent, with destructive consequences for communal harmony, cohesion and nation building. Thus, instead of creating a situation in which the citizenry is mobilised and empowered to participate effectively and take ownership of the process of constitution making, Nigeria's neo-patrimonial elites - military and civilian - arrogate to themselves the responsibility to organise constituent assemblies and commissions that draft constitutions.

As a living document that defines power relations, rights and obligations within a sovereign state, a constitution also serves

... as a basis for controlling state power and involving the people in the political process, and should clearly articulate the aspirations of all communities and individuals in society. It must directly go to the heart of engaging not only those contentious issues that shape politics and power, but also those that shape the larger society, and breed distrust, tolerance and violence.

Ihonvbere 2000

An examination of the legal and constitutional framework of Nigeria's elections must, therefore, necessarily include a critical analysis of the nature of the Nigerian post-colonial state, the ways in which the dominant elite appropriates power and the erosion of the rule of law, which subverts the enthronement of a stable democracy in the postcolony (Mbembe 2001).

In examining the challenges of multiparty democracy and constitutionalism in Nigeria several pertinent questions arise: firstly, what are the structural and institutional impediments to the conduct of free, fair and legitimate elections in the country? Secondly, how does the authoritarian and neo-patrimonial configuration of state power in post-colonial Nigeria affect the process of constitution making? Thirdly, in what ways do elite predation and the criminalisation of federal power undermine the democratisation process? Fourthly, what are the implications of 
the above for national coherence, political stability and nation building in the country?

In discussing these questions the article draws empirical examples from Nigeria's 2011 elections and related socio-political developments in the postcolony since the return to democratic rule in 1999. Reference will be made to the regime of Olusegun Obasanjo (1999-2007) as a historical backdrop, as well as to the People's Democratic Party (PDP) regime that conducted the 2011 elections, with a view to unravelling what links state power, the governmental appropriation of power resources, elections and the travails of constitutionalism.

The paper is divided into four sections. The first sketches a theoretical framework by drawing on the literature on Foucault's notion of governmentality and the practices of state power as deployed in Nigeria's political landscape of elections and battles for office. Foucault's admonition that 'he who governs must only govern to the extent that he thinks and acts ... in the service of those who are governed' (cited in Curtis 2002) underlines the essence of democracy and the practice of power. Section two examines critically the notion of garrison politics through a discussion of the Obasanjo regime and the ruling PDP and its effects on electoral process and state legitimacy.

I argue that the PDP coalition, which consists of elites drawn from all six geopolitical zones in the country, appropriates the resources of the state to ensure its stranglehold on the citizenry. Its pattern of governance through neopatrimonialism and distribution of federal largesse to clients at national, state and local levels further deepens corruption and the intensification of political violence at the local level (Kendhammer 2010).

The third section returns to the subject of the 2011 elections, the legal and constitutional framework of the electoral process, the outcome of the election and the subsequent outbreak of violence, especially in the northern parts of the country. I argue in this section that the ethno-regional antecedents of Nigeria's political parties and the emergence of presidential flagbearers, Buhari, from the North, and Jonathan, from the South, deepened the zero-sum contestation for presidential power along an explosive fault line of religious faith. Furthermore, although the 2011 election was considered to have been relatively free and fair, the sudden outbreak of violence is a reminder that the dominant neo-patrimonial elites and their acolytes are yet to imbibe the crucial democratic ethos of accepting the outcome of an election.

Section four concludes with proposals for entrenching participatory democracy through credible and legitimate elections in Nigeria as a mechanism for averting ethno-religious violence and state decline. 


\section{STATE POWER, GOVERNMENTALITY AND CONSTITUTIONALISM: TOWARDS A THEORETICAL FRAMEWORK}

In his seminal work analysing the technology of power and its utilisation by dominant elites to ensure hegemony in the field of political practice, Foucault draws our attention to the important concept of governmentality as a complex ensemble of procedures, practices, institutions, strategies and tactics through which authorities not only seek to define, guide and shape the conduct of the population but also set the agenda and decision-making processes within the polity to accomplish specific objectives (Lemke 2007; Jessop 2007).

For Foucault, an understanding of state power and its manifestations through government cannot be reduced to the juridico-political instance, rather, power must be conceptualised within the framework of '... government as strategic codification of power relations ...' (Jessop 2007). According to Foucault (2004b), power must be understood in the first instance:

... as the multiplicity of force relations immanent in the sphere in which they operate and that constitute their own organization; as the process which, through ceaseless struggles and confrontations, transforms, strengthens, or reverses them; as the support which these force relations find in one another, thus forming a chain or a system, or, on the contrary, the disjunctions and contradictions that isolate them from each other; and, lastly, as the strategies in which they take effect, whose general design or institutional crystallization is embodied in the state apparatus, in the formulation of the law, in various social hegemonies.

This perspective on the notion of state power draws our attention to the relevance of interrogating government policies such as elections and election administration, election observation, constitution drafting, inauguration, and so on, as techniques of power and the exercise of social and political domination. Another pertinent aspect of Foucault's conceptualisation of power is the notion of governmentality, which refers to

the ensemble constituted by the institutions, procedures, analyses, and reflections, the calculations and tactics that permit the exercise of this quite specific, albeit very complex form of power, which has as its target, population; as its main form of knowledge, political economy; and, as its essential technical means, apparatus of security. 
The relevance of Foucault's analysis of power and governmentality to an understanding of the challenges of democratisation through elections and constitutional engineering in postcolonial contexts such as that of Nigeria is that it enables us to begin to understand why, for instance, the state deploys not only its police but also the army as apparatuses of power in the name of 'free and fair' elections.

It also enables us to begin to analyse aspects of the 1999 Constitution, which asserts, for example, in the preamble that 'We the people of the Federal Republic of Nigeria: having firmly and solemnly resolved to live in unity and harmony as one indivisible and indissoluble sovereign nation ...' This claim contradicts the historical reality of the origins of the Constitution, which was not a document into which a broad spectrum of Nigeria's populace had an input. Rather, it was primarily a document that was elite driven and crafted by the military as it exited power.

When and where did the more than 500 nationalities of Nigeria make the solemn declaration? Thus, Foucault's notion of power and governmentality enables one to decipher the strategies deployed by the elites to ensure domination within the new dispensation of civilian rule.

Election rigging in Nigeria takes place not just on election days, it starts with the statistical compilation of the voters' register. From a Foucauldian perspective the technique of counting, compiling, registering and organising the citizenry in a government-driven project reveals the way in which hegemonic power is deployed. The absence of a people-driven constitution certainly not only undermines the legitimacy of the democratic process but exacerbates cynicism, a lack of participation and disengagement from the nation-building project (Baker 1997).

Several scholars contend that between the 1980s and the 1990s, when the transition from one-party and military authoritarian regimes to multiparty democracy in Africa began, the failure of several countries to engage a broad spectrum of the citizenry in the process of crafting constitutions created disillusionment and, in some instances, violent conflict (Ihonvbere 2000; Ake 2003; Adejumobi 2000; Suberu 2007; Lewis 1994; Branch \& Cheeseman 2008; Shivji 1991; Olukoshi \& Agbu 1996).

This line of theorisation about Africa's democratisation insists that the process of constitution making is fundamental to the enthronement of participatory democracy and accountability in the exercise of state power in postcolonial Africa. Constitutions, as Ihonvebere (2000) contends, not only define the power, rights and obligations of the citizenry they also assert the sovereignty of the state and articulate the aspirations of all the communities and individuals in society. Drawing on the works of Shivji, Ihonvebere (2000) defines constitutionalism as: 
a process for developing, presenting, adopting and utilizing a political compact that defines not only the power relations between political communities and constituencies, but also the rights, duties, and obligations of citizens ... Two elements are critical in the notion of Constitutionalism: first, the process dimension which includes constitution making and the extent to which it is popular, inclusive, participatory or process-led, and democratic; and second, the available openings, institutions and processes of making the constitution a living document by taking it to the people so that they are in a position not just to have access to it, but also to understand it, claim ownership and use it in the defense of the democratic enterprise.

The concept of constitutionalism, therefore, enables us to begin to interrogate Nigeria's democratic project along the following lines of inquiry: to what extent did the 1999 Constitution provide an inclusive platform for the participation and civic engagement of the citizenry? Why is there thuggery, violence and a rampant breakdown of law and order, especially during elections? To what extent does the Constitution strengthen the legitimacy of the state and entrench the rule of law? In what ways did the elite appropriate the process of constitution making in Nigeria and entrench its interests in the structures and institutions of state power? How does this undermine the democracy project?

In the next section, I turn to these questions by examining Nigeria's Fourth Republic, particularly focusing on the Obasanjo era (1999-2007) and the conduct of the 2011 elections that brought President Goodluck Jonathan to power. I argue that Obasanjo's military antecedents not only entrenched garrison strategies and mentalities in the conduct of electoral process (Omotola 2009; Figueroa 1994; 2002; Stone 1980; Suberu 2007) but also deepened neo-patrimonial practices in the distribution of federal largesse, thereby engendering the stability of the polity.

It is important to underline from the outset that my use of the notion of 'garrison' relies more on its initial conceptualisation by Laswell (1941), to describe a state 'which has undergone militarization, resulting in a society which is dominated by technocrats from the [civil and] military establishment, and which privileges militaristic culture and policy imperatives over others' (cited in Bernazzolli \& Flint 2010).

The outbreak of violence after the 2011 elections reveals a deeply fractured Nigerian polity in which the majority of citizens live in penury, abject neglect and illiteracy while the dominant military and technocratic elite appropriates and siphons national wealth through primitive accumulation and launders it in Western financial institutions for its private gain.

It is in this context that Foucault's analytical framework of government and 
its connections with the concept of state power, institutions, practices and garrison mentalities in the postcolony provides us with the conceptual tool for unpacking the dilemmas of Nigeria's democratisation and nation-building project. It is also within this framework that we can fruitfully interrogate the legal and constitutional parameters of elections in Nigeria since the return to civilian rule in 1999.

\section{THE GARRISON MENTALITY AND THE TRAVAILS OF CONSTITUTIONALISM IN NIGERIA}

Elections are an essential ingredient of democracy because they provide citizens with a means of participating not only in choosing their representatives but also in holding leaders accountable in the exercise of state power and practices. As Lindberg (2009) rightly contends, '...the inception of multiparty elections ... initiates liberalization, and repeated electoral activities create incentives for political actors, fostering the expansion and deepening of democratic values'. For Lindberg, as well as other scholars such as Bratton \& Van de Walle $(1997 ; 2007)$, Diamond (1999), Joseph (1997), Gyimah-Boadi (2004) and Adejumobi (2000), the return to democratic rule that swept across the African continent in the 1980-90s was marked by competitive multiparty elections that inaugurated the transition process.

While some of these elections indeed entrenched relatively stable democratic systems of governance in countries such as Ghana and South Africa, in Nigeria the return to civil rule has been characterised by a rising tide of ethno-religious violence, insecurity, intimidation of opposition parties, declaration of states of emergency by the federal government and the resurgence of terror-related violence, especially in Northern Nigeria.

The inauguration of the Obasanjo regime in May 1999 marked the beginning of the Fourth Republic. It was the 1999 Constitution, decreed by the departing military regime of General Abdulsalam Abubakar, that provided the legal foundation of the Fourth Republic. Chapter 1 sub-sections 1-3 of the Constitution not only emphasise the supremacy of the Constitution but state that 'The Federal Republic of Nigeria shall not be governed, nor shall any person or group of persons take control of the government of Nigeria or any part thereof, except in accordance with the provisions of this Constitution.'

It goes further to assert that in cases of inconsistency with 'any other law' the provisions of 'this constitution shall prevail, and other law shall to the extent of the inconsistency be void' (Constitution 2011). Although these provisions clearly insist on the supremacy of the Constitution as the legal foundation of the rule of law in Nigeria's Fourth Republic there have been instances when its efficacy has been challenged by competing ethnic and religious groups. 
For example, from late 1999 through 2000, 12 of the 19 northern states introduced Shari'a law, which raised communal tensions culminating in violence between Christians and Muslims, especially in Kaduna, Kano and Jos. Instead of asserting the supremacy of the Constitution, President Obasanjo and the attorneygeneral of the federation preferred to take a conciliatory tone, claiming that Shari'a was only a political agenda deployed by the northern elite to extract concessions from the centre.

While it may be true that the 12 northern governors who wished to implement Shari'a in their states had political agendas, especially in terms of gaining religious legitimacy with the predominantly Muslim constituencies, Obasanjo's failure to ensure the supremacy of the Constitution as stated in Chapter 1(3) only provided a means for the extremist groups that emerged from mid-2005 to challenge the secularity of the state.

The continuing violence unleashed by the Yussifiyya Movement (also known as Boko Haram) from 2009 to date represents a major challenge for constitutionalism and the rule of law in the country. At both federal and state levels the response of the regime to this challenge has been within the context of what can be described as a garrison mentality whereby troops are deployed to contain the violence but the outcome is more anarchy, insecurity, communal distrust and the destruction of human lives and property, especially in the north-eastern states of Borno and Yobe.

A nuanced interrogation of the complex dimensions of this crisis and its legal and constitutional implications for the stability and coherence of the Nigerian federation is beyond the confines of this paper. Suffice it to say that the Shari'a controversy, the post -2011 election violence and the Boko Haram challenge not only reveal the contradictions of constitutionalism in Nigeria's multicultural society but, even more importantly, indicate that the problem requires urgent attention.

In the absence of communal peace, security and civic trust, participatory democracy through open, transparent and accountable institutions for the conduct of elections cannot take root in a society. Instead, garrison mentalities and practices in the form of the militarisation of society (through the deployment of soldiers on election days or to maintain 'law and order'), thuggery, election rigging, sectarianism and the manipulation of ethno-religious identities for personal gain become entrenched in the state structures and society.

Chapter 2 of the 1999 Constitution focuses on the fundamental objectives and directive principles of state policy. In s 14(2) the framers of Constitution state that:

a) ... sovereignty belongs to the people of Nigeria from whom government through this Constitution derives its powers and 
authority; (b) the security and welfare of the people shall be the primary purpose of government; (c) the participation by the people in their government shall be ensured in accordance with the provision of this Constitution.

These cogent directive principles and aspirations are, indeed, critical elements in the democratic process. In addition to entrusting sovereignty to the people the Constitution clearly articulates the primary responsibility of the government, which is the security and welfare of the citizenry and ensuring that the people participate in the affairs of governance.

One of the core elements of such participation is obviously through elections. The process of elections not only ensures that government derives its legitimacy from the people but, even more importantly, it underlines the norm of accountability, namely that in the exercise of its functions and powers the government, at all levels, must be accountable to the people.

Although Nigeria has had a plethora of constitutions - ten between 1922 and 1999 (1922, 1946, 1951, 1954, 1960, 1963, 1979, 1989, 1995 and 1999) - the struggle to ensure free and fair elections as well as the accountability of elected representatives to their constituents remains a major challenge. As Agbaje (2004) correctly observes, 'much attention has gone into the making of constitutions, but little success has been achieved in ensuring that governments govern according to the constitution and that the rule of law is enforced in place of capricious governance'. The challenge, therefore, remains that 'while Nigeria has produced many constitutions, it has yet to entrench constitutionalism' (Agbaje 2004).

As a creature of the colonial project, and appropriated by the postcolonial elite for predatory pillage, the Nigerian state and its apparatuses remain ensconced on the one hand as instruments of violence against the citizenry and, on the other, a repressive structure for the extraction and plunder of the national wealth and resources.

In terms of aspirations for national integration and citizenship, s 15 (subss 2-3) of the 1999 Constitution states that '...national integration shall be actively encouraged, while discrimination on the grounds of place of origin, sex, religion, status, ethnic or linguistic association or ties shall be prohibited ...' and that 'it shall be the duty of the state to: (a) provide adequate facilities for and encourage free mobility of people, goods and services through out the Federation; and (b) secure full residence rights for every citizen in all parts of the Federation.'

Although these are genuine aspirations aimed at enhancing the integration of Nigeria's diverse ethno-religious and linguistic groups into a coherent nation, the daunting challenges of 'indigenes' $\mathrm{v}$ 'settlers' has remained a major source of violent conflict in the federation. 
Jos Plateau, in particular, has, for the past two decades, been a region of incessant identity driven conflicts between predominantly Christian indigenous groups such as Anaguta, Angas, Mwagavul and Birom and the Muslim HausaFulani people who migrated to the region during the colonial epoch. The creation of the Jos-North Local Government Area Council under the Babangida regime raised the stakes significantly in the battle over the ownership of Jos township and, by implication, access to related economic resources such as land and state sponsored scholarships to universities as well as to traditional power.

Since the return to civilian rule in 1999, elections for the Jos-North local government have generated violent conflict between the indigenous groups and the Hausa-Fulani settlers. More often than not such conflict spreads to other parts of the state and takes on religious dimensions along Christian-Muslim fault lines, with devastating consequences for all the communities. For example, in 2004 a generalised violence arising from local government elections engulfed not only the Jos metropolitan area but also the southern part of the state around the YelwaShendam axis, prompting President Obasanjo to declare a state of emergency after removing Governor Joshua Dariye.

Although Dariye was reinstated after the army restored some measure of peace in the Jos Plateau, the state continues to experience recurrent outbreaks of communal violence. While the 1999 Constitution clearly prohibits discrimination based on place of origin, religion or ethnic affiliation, the issue of citizenship, which is central to the democratic ethos of free participation in elections, is undermined by the failure of the federal government to articulate effectively a policy on residency and citizenship in Nigeria.

Consequently, elections in several parts of the country where there are migrant communities become the fulcrum for violent outbursts of communal conflict between indigenous groups and settlers, while political parties exploit these communal ethno-religious identities to secure electoral votes. Human Rights Watch estimated in 2007 that more than 11000 people had died as a result of ethnoreligious and political violence in Nigeria since the return to civil rule in 1999.

These battles, in turn, further complicate communal relations and entrench violent conflict. Simply put, identity-driven conflicts over issues of citizenship and belonging further reveal how the dominant elite in Nigeria has appropriated identity differences as strategies for access to state power and resources.

Under the Obasanjo regime the 2003 and 2007 elections were characterised by open vote rigging, ballot box stuffing and snatching as well as the phenomenon of 'godfatherism', through which wealthy and influential oligarchs from specific ethnic or regional 'geo-political zones' in the country ensured that their preferred 'candidate' won the elections either at local, state or national level to enable them to gain access to power and largesse through patronage. 
The Independent National Electoral Commission (INEC), which is constitutionally mandated to conduct elections, is, unfortunately, beholden to the executive. The chairperson and the commissioners are appointed by the president and until recently the commission's budgetary allocation came from the presidency.

During the 2003 election, for example, the president did not release the necessary funds to INEC until ' . .. just forty-eight hours before polling day' (Kew 2004). The attempt by President Obasanjo and the PDP leadership to tamper with the electoral law in 2001-2002 in favour of the incumbent government was thwarted by a Supreme Court ruling. This action and the legal wrangling over the electoral laws not only increased INEC's logistical constraints in conducting voter registration, more importantly, it made it virtually impossible to conduct the constitutionally mandatory triennial local government area (LGA) council election.

The president, along with the PDP leadership at the national level, '... arranged for the governors to appoint caretaker committees to run all local governments, [thereby] delaying LGA elections until 2004. In the interim, the governors packed the LGA Councils with their loyalists to ensure that they will get support when elections are held' (Kew 2004).

It is clear from the above that the presidency and the ruling PDP were more concerned with entrenching themselves in power than with the public good. By ensuring that local government councils are filled with their appointed loyalists at the state level, the ruling PDP, as well as the presidency, deployed public resources in the pursuit of private ends. Thus, under the Obasanjo presidency political power and institutions of the state were appropriated to ensure the hegemony of the dominant PDP not only at local but also at national level. The garrison mentalities of President Obasanjo's regime and the PDP leadership subverted the constitutional foundations of the Fourth Republic, thereby opening the floodgate for corruption, electoral malfeasance, political assassinations, ethno-religious violence and, subsequently, degeneration into brigandage and sectarianism.

Neo-patrimonial networks within traditional, ethnic, religious, regional and party structures became the mechanisms for the politics of 'cash-and-carry', in which the rule of law had no place. Furthermore, decades of military autocracy not only reinforced patronage and clientelism but, most importantly, exacerbated the looting of state resources at all levels of governance. In the words of Kew (2004):

... as the generals spread [the] largesse to their civilian allies, the civilians, too, extended or built extensive client networks across ethnic lines, diluting the ethnic element in the prebendal networks 
and giving increasingly less of their plunder back to their home communities. These rich and powerful civilian allies of the military, and some of the military leaders themselves upon retirement, became [the] Big Men [or godfathers] - the driving force in Nigerian politics. They often maneuver within traditional ethnic and regional patterns, but increasingly they do so across the universal logic of financial realpolitik.

In the absence of free and fair elections based on the rule of law and constitutionalism, democracy in Nigeria runs the risk of being bastardised by a competitive oligarchy dominated by 'Big Men' with networks that cut across ethnic, regional, religious and gender lines. It is within this context that we can decipher the 2011 election and its violent aftermath. Although the post-election violence was primarily in Northern Nigeria, understanding its ramifications and implications for the polity requires a nuanced analysis that takes on board the broader national patterns of party alliances, affiliations and contestations for the plum office of president, which bestows enormous power and access to state resources.

\section{THE 2011 ELECTIONS AND THEIR AFTERMATH}

It is within the broader context of the 1999 Constitution; the decades of debate and wrangling over issues of Shari'a and its place in Nigeria's legal system; contestations and violent sectarian conflicts, especially in the Jos Plateau, over issues of citizenship, religious identities and belonging; INEC's financial dependence on the presidency; President Obasanjo's failed attempt to tamper with the Constitution and obtain a third term and the ascendance of PDP stalwarts wealthy 'Big Men' and godfathers - that we can effectively understand the shortlived reign of President Umaru Musa Yar'Adua and the subsequent emergence of Goodluck Jonathan.

I argue that it is through a nuanced Foucauldian analytical framework of governmentality and Carl Stone's notion of garrison mentalities (Stone 1980), strategies, calculations, contestations and practices of power within and between different factions, fractions, and group alliances that we can decipher the calamities that followed the 2011 presidential election.

In his analysis of Jamaica's violent political ethos in the 1970s and 1980s Stone (1980) uses the concept of 'garrison politics' to describe the links among the urban landscape of government housing ('garrison phenomena'), homogeneous voting, electoral manipulation and violence against members of opposition parties. As Figueroa \& Sives (2002) put it, the concept of a garrison represents '... a veritable fortress where the dominant party and/or its local agents/supporters are able 
to exercise control over all significant political, economic and community related social activities'.

Garrison communities, which emerged around large government-sponsored housing schemes that were distributed along patronage networks in Jamaica, became lucrative platforms for mobilising votes and manipulating the outcome of elections. Opposition to the dominant party by an individual or group within a garrison community may lead to physical danger '... thus making continued residence in the area extremely difficult, if not impossible' (Figueroa \& Sives 2002). Thus, the garrison political and social space is not only characterised by patronage networks, electoral manipulation and distribution of largesse from the state, more importantly, it is also an autocratic and militaristic space where subjection of its members is paramount. Garrison mentalities revolve around issues of power, strategies of control and the extension of patronage networks for the purpose of exclusion by inclusion as well as turf politics in which competing parties seek to control their territory or extend it to other areas as part of the electoral strategy.

In Nigeria since the First Republic (1960-66) ethno-regional parties have dominated the political scene and entrenched their influence within their respective territories or garrisons. Regional governments in the north were dominated by the Northern People's Congress (NPC), in the west by the Action Group (AG) and in the east by the National Council of Nigerian Citizens (NCNC). Each political party not only guarded its regional turf it ensured that opposition to the regional government or encroachment would not be tolerated.

Military rule, which lasted through most of the 1980s and 1990s, further reinforced patronage, corruption and the pillage of the national treasury. The oil boom of the 1970s provided the federal centre with enormous resources. The politics of state and local government became platforms for the redistribution of the oil largesse from the centre. Thus, following the return to civilian rule in 1999, the dominant parties that emerged, namely the PDP, the Alliance for Democracy (AD) and the All Nigeria Peoples Party (ANPP) were, to some extent, replicas of the regionally based parties of the first, second and third republics, with retired military generals and civilian technocrats who had enormous wealth to use to control the outcome of elections.

Regional, ethnic and religious identities remained entrenched as channels of communal social existence as well as mechanisms for patronage networks and prebendalism (Joseph 1987). As Obasanjo's third-term agenda was thwarted he strongly supported the candidacy of Yar'Adua (the younger brother of General Shehu Musa Yar'Adua who was General Obasanjo's chief of staff during the military era from 1976 to 1979). As Suberu (2007) put it,

Obasanjo's endorsement of the ... frail Yar'Adua for PDP's 
nomination sidelined other aspirants, including several prominent governors. Thus, the PDP's December 2006 presidential primary not unlike the undemocratic primaries held by several of the country's forty nine parties, became a coronation for Yar'Adua rather than a democratic contestation.

Obasanjo set the tone for the 2007 presidential election campaign by describing it as a 'do-or-die' affair (Suberu 2007). The north thought power had returned to it through the discredited 2007 elections but President Yar' Adua died in office in May 2010 after a protracted illness, paving the way for the accession of the South-South minority's Goodluck Jonathan to the presidency.

It should be noted that during the Obasanjo era (1999-2007) some individuals who opposed the president's third-term agenda were subjected to a witch-hunt by the Economic and Financial Crimes Commission while others were disqualified by INEC from standing for election. Opposition parties and candidates from the $\mathrm{AC}$ and ANPP were intimidated by the police or detained and their offices and campaign headquarters were ransacked.

Obasanjo's vice-president, Atiku Abubakar, who defected from the PDP to stand for the AC, was one of the casualties of this brazen and authoritarian garrison mentality. The 2011 election was, therefore, conducted in the shadow of the discredited 2007 election which had brought the image of Nigeria into disrepute in the international community.

During his inauguration Yar'Adua observed that the 2007 election had fallen short of even the minimum standards of democratic process and the rule of law. Thus, in 2008, he appointed a 22-member Electoral Review Committee (ERC) presided over by Justice Mohammadu Uwais. The primary mandate of this committee was to 'examine the entire electoral process with a view to ensuring that we raise the quality and standard of our general elections and thereby deepen our democracy' (EU 2011). In its report, delivered in December 2008, the Uwais committee observed that the quality and credibility of elections in Nigeria was affected by factors such as the weakness of the constitutional and legal framework, the lack of financial and institutional autonomy of INEC, the absence of intra-party democracy and the prevalence of impunity during and after elections.

According to the committee there was a fundamental link between the conduct of free, fair, credible and acceptable elections and the consolidation of democracy and the role of the citizenry in this process constitutes one of the core defining elements of democracy. As they put it, in a democracy,

... the role of the people is to produce a government and elections are the institutional arrangement for arriving at political decisions 
in which individuals acquire the power to decide by means of competitive struggle for the people's votes. Elections are thus often perceived as a procedure for regulatory competition for political power through competition for votes. Within this conception, elections are fundamental building blocks for democracy. Failure to conduct credible and acceptable elections in a polity often generates outcomes that stunt the growth of democracy, on the one hand, and the development of the nation, on the other.

Electoral Reform Committee 2008

Among the committee's recommendations for improving the quality of the electoral process were that INEC be more autonomous and that an electoral offences commission, a political parties registration and regulatory commission and a constituency delimitation commission be established.

The legal instruments for the conduct of elections in Nigeria include the 1999 Constitution, the 2010 Electoral Act (as amended), the Criminal and Penal Code, the Police Act and the Guidelines for the Conduct of Police Officers on Electoral Duty. The Electoral Act of 2010 not only sets out the functions of INEC, it identifies the procedures for elections, the conduct of political rallies, electoral offences and procedures for the determination of electoral offences. For example, ss 117 and 118 describe an electoral offence as one including actions by an individual who '... without authority, destroys, mutilates, defaces or removes or makes any alteration in any notice or document required for the purpose of registration ...'; or a person who 'prints a ballot paper or what purports to be or is capable of being used as a ballot paper or result form at an election'. It also prescribes the penalties for such electoral offences. These include sentences of a maximum fine of N50-million or a term of imprisonment of not less than 10 years, or both (Electoral Act 2010).

To ensure the probity of election officials s 123(5) of the Act stipulates that ‘[a\}ny Returning Officer or Collation Officer who delivers or causes to be delivered a false certificate of return knowing same to be false, commits an offence and is liable on conviction to a maximum imprisonment for three years without an option of fine.'

But while the Act provided the enabling legal framework for the conduct of elections it made no provision for voters to file complaints about breaches of the law during polling, counting or the collation of election results. Furthermore, it did not specify deadlines or clear mechanisms for the publication of results, nor did it provide sufficient guarantees of and sanctions for the exclusion or inclusion of suspicious results during collation.

Nigeria's electoral management model, whereby INEC and related agencies at state and local levels are extensions of the executive branch of government, 
certainly compromises their neutrality during elections. The shortcomings of the Electoral Act were some of the issue areas around which violence erupted in some parts of the country following the announcement of the 2011 presidential election results that brought Jonathan to power.

The elections, scheduled for April, included the presidential election as well as balloting for 26 governorship positions, 109 senatorial positions, 360 members of the House of Representatives and 990 legislators for 36 state houses of assembly (EU 2011). The major political parties that contested the elections include the PDP, whose presidential candidate was Goodluck Jonathan; the Action Congress of Nigeria (ACN), with Nuhu Ribadu as its flag bearer; the Congress for Progressive Change (CPC), who fielded Mohammadu Buhari, and the ANPP, with Ibrahim Shekarau as its candidate.

While all the candidates campaigned vigorously, the PDP, which had the advantage of incumbency, used state resources, especially the media, to boost its access to the electorate. The opposition parties, especially the CPC, criticised the PDP vigorously for its flagrant misuse of state power and resources to capture votes. In the end, the contest was essentially between Jonathan, a Southern Christian from a minority group, and the CPC's candidate, retired General Muhammadu Buhari, who is a Northern Muslim of Hausa-Fulani extraction.

The implication of this is that it literally coincided with Nigeria's ethnoreligious and regional fault lines, which had, hitherto, been a source of acrimony and identity driven conflict in the country. The predominantly Islamic Northern State, which had earlier adopted Shari' a law as part of its legal system, saw the CPC and its candidate as representing their values, while the Christian South, along with minority groups in the Middle Belt, favoured the PDP and its candidate.

The statement by the Sultan of Sokoto on the eve of the elections, describing Jonathan as the 'son of the Sultanate' reveals the complexities of Nigeria's politics as well as the neo-patrimonial dimensions of power relations in the federation. Suffice to say that for the average northern Muslim who supported the CPC, the Sultan's statement may have been seen as a sacrilege; thus, the palace of the Sultan - though the highest source of Muslim authority in Nigeria - was attacked when the results of the election were announced. On 8 April a bomb exploded in the INEC office in Suleja, Niger State, killing 11 people and injuring another 30. The EU Report describes the ensuing violence thus:

After the Presidential elections on 18 April, violence erupted in the North and in the Middle Belt of the country including Kano, Kaduna, Gombe, Bauchi, Adamawa and Taraba States, probably triggered by the perception of the presidential results. Protesters burned places of religious worship, public buildings and the houses of politicians 
from the ruling PDP, targeted INEC buildings and its personnel, including the National Youth Service Corps members serving as INEC ad hoc staff and in Bauchi State ten of them were killed in a gruesome manner ... Protesters clashed with the security forces. In total some hundreds of persons were murdered and tens of thousands were displaced. The authorities imposed a curfew in the affected States until heavy military presence restored order in the following days. In the afternoon of 21 April, INEC Chairman [Attahiru] Jega announced that due to the security situation, the gubernatorial elections in Bauchi and Kaduna States were postponed from 26 to 28 April.

EU 2011

The PDP candidate won $58.87 \%$ of the vote, his closest rival, from the CPC, won barely $31.97 \%$, while ANPP and ACN candidates won $2.40 \%$ and $5.44 \%$ respectively. The latter two accepted the outcome of the election, but Buhari insisted the PDP had rigged the election, especially in the southern parts of the country, and decided to go to the courts for legal redress. Table 1 shows the results of the 2011 presidential election, while Tables 2 and 3 show those of the Senate and House of Representatives elections respectively. According to these data, of the 109 senatorial seats the PDP won the largest number - 71, the ACN 18, the ANPP 7 and the Labour Party 4, while minority parties such as the APGA and the DPP won 1 each. Similarly, in the House of Representative contests, the four dominant parties, namely the PDP, ACN, CPC and ANPP won 199, 69, 37 and 27 seats respectively.

Table 1

Presidential Election Results 2011

\begin{tabular}{|l|c|c|c|c|c|}
\hline & ANC & ANPP & CPC & PDP & OTHER \\
\hline North Central & $6 \%$ & $1 \%$ & $31 \%$ & $61 \%$ & $1 \%$ \\
\hline North East & $2 \%$ & $5 \%$ & $58 \%$ & $35 \%$ & $2 \%$ \\
\hline North West & $10 \%$ & $4 \%$ & $53 \%$ & $32 \%$ & $1 \%$ \\
\hline South East & $1 \%$ & $1 \%$ & - & $98 \%$ & - \\
\hline South-South & $2 \%$ & - & $1 \%$ & $96 \%$ & $1 \%$ \\
\hline South West & $30 \%$ & $1 \%$ & $5 \%$ & $62 \%$ & $2 \%$ \\
\hline Total & $5.44 \%$ & $\mathbf{2 . 4 0} \%$ & $31.97 \%$ & $58.87 \%$ & $\mathbf{1 . 3 2} \%$ \\
\hline
\end{tabular}


An important aspect of the presidential election result is the dominance of the PDP and CPC in their respective ethno-regional enclaves, from which their presidential candidates came. While the CPC had most of its electoral successes in the North, the PDP won most of its votes in the South. The post-election violence was primarily in the northern states because of the perception that the PDP had rigged the election in favour of Jonathan, who is from the South. The CPC and its supporters contended that the figures of $98 \%$ from the South-South zone and $96 \%$ from the South East were an indication of electoral fraud.

Table 2

Senatorial Election Results 2011

\begin{tabular}{|l|r|r|r|r|r|r|r|r|}
\hline & ACN & NPP & APGA & CPC & DPP & LP & PDP & TOTAL \\
\hline North Central & 1 & - & - & 2 & - & 1 & 14 & 18 \\
\hline North East & - & 4 & - & - & - & - & 14 & 18 \\
\hline North West & - & 3 & - & 5 & - & - & 13 & 21 \\
\hline South East & 1 & - & 1 & - & - & - & 13 & 15 \\
\hline South-South & 2 & - & - & - & 1 & - & 16 & 19 \\
\hline South West & 14 & - & - & - & - & 3 & 1 & 18 \\
\hline Total & $\mathbf{1 8}$ & $\mathbf{7}$ & $\mathbf{1}$ & $\mathbf{7}$ & $\mathbf{1}$ & $\mathbf{4}$ & $\mathbf{7 1}$ & $\mathbf{1 0 9}$ \\
\hline
\end{tabular}

Source: EU 2011

The data reveal that the PDP continued to exert its dominance in the Senate, winning $65.14 \%$ of the total seats, while its closest rival, the ACN, won only $16.51 \%$, the CPC and ANPP 6.42\% each, the LP 3.67\% and the DPP and APGA $0.92 \%$ each. The PDP won several seats in the five geo-political zones but was defeated in the South West by the ACN, which won 14 senatorial seats. It is likely that the electorate in the South West was casting a protest vote against former President Obasanjo, who was critical of other Yoruba elder statesmen such as Bola Tinubu and the governor of Ondo state.

The House of Representative election results (see Table 3) show the PDP's dominance across the five geo-political zones, with the exception of South West, where the rival ACN clinched 53 seats in the lower house of the National Assembly. Another aspect of the results featured in Table 3 is that they show how smaller parties such as the ACN, APGA, ANPP and LP are primarily regional parties which may have consolidated their hold within the ethno-linguistic enclaves and thus avoided the dominance of the PDP or CPC. 
Table 3

House of Representatives Election Results 2011

\begin{tabular}{|l|c|c|c|c|c|c|c|c|c|c|}
\hline & ACCORD & ACN & ANPP & APGA & CPC & DPP & LP & PDP & PPN & Missing* \\
\hline $\begin{array}{l}\text { North } \\
\text { Central }\end{array}$ & - & 5 & 1 & - & 8 & - & - & 37 & - & - \\
\hline $\begin{array}{l}\text { North } \\
\text { East }\end{array}$ & - & 2 & 12 & - & 7 & - & - & 27 & - & - \\
\hline $\begin{array}{l}\text { North } \\
\text { West }\end{array}$ & - & - & 13 & - & 22 & - & - & 55 & - & 2 \\
\hline $\begin{array}{l}\text { South } \\
\text { East }\end{array}$ & - & 1 & 1 & 6 & - & - & - & 31 & - & 3 \\
\hline $\begin{array}{l}\text { South- } \\
\text { South }\end{array}$ & 1 & 8 & - & - & - & 2 & - & 43 & - & 1 \\
\hline $\begin{array}{l}\text { South } \\
\text { West }\end{array}$ & 4 & 53 & - & - & - & - & 8 & 6 & 1 & - \\
\hline Total & 5 & $\mathbf{6 9}$ & $\mathbf{2 7}$ & $\mathbf{6}$ & $\mathbf{3 7}$ & $\mathbf{2}$ & & & & $\mathbf{6}$ \\
\hline
\end{tabular}

Source: EU 2011

* Election results from constituencies were not presented at collation centres

According to Human Rights Watch (2011), by 2011 a total of 14800 people had died as a result of inter-communal, political and sectarian violence in Nigeria in the 12 years since the return to democratic rule. Why should this be? Why have the governments at national, state and local levels failed in their primary responsibility to ensure the security of lives and property in the country?

Part of the explanation for the deterioration of peace and stability in postcolonial Nigeria may be located in the absence of transparent, effective, accountable and autonomous institutions of state that are able to ensure adherence to the rule of law and a democratic ethos. The appropriation and domination of the structures of the postcolonial state by the neo-patrimonial elite in Nigeria for the pillage of national wealth through predatory garrison politics undermines the neutrality of the state vis-à-vis society.

Thus, for the average Nigerian, the state and its apparatuses have failed in the primary task of social provisioning in areas such as employment, education, health services, infrastructure and, above all, enthroning a democratic space for the exercise of individual freedom and liberty through the electoral process. Thus, ethnic and religious identities have increasingly become the platforms 
for political mobilisation, thereby exacerbating violent zero-sum battles during national elections.

\section{CONCLUSION}

In order to ensure peace, security, stability and socio-economic development within the framework of a democratic order, Nigerians and their leaders must rethink the imbalance in the federal structure, particularly in the allocation of resources. The Constitution should be amended to ensure a balanced distribution of national wealth.

Another important reform should relate to the electoral process. The current first-past-the-post system, with its winner-takes-all premise, exacerbates a zerosum approach to political contests in which losing becomes a dreaded outcome that none of the actors wishes to accept. It is, therefore, imperative to incorporate a proportional representation system, particularly for elections to the House of Representatives, state houses of assembly and local government councils (Electoral Reform Report 2008). A mixed electoral system in a multicultural and multireligious country such as Nigeria will not only deepen the inclusion of diverse groups in the decision-making centres of power, most importantly it will enhance the empowerment of society.

The current political framework, in which power is centralised and appropriated by the elites through corrupt elections and a garrison mentality and practices, undermines the enormous potential of citizens, leading to the type of communal and sectarian violence exemplified by the Jos Plateau crises and the Boko Haram carnage in the North. It is, therefore, imperative to devolve more power and resources to the local levels through democratic, inclusive, and transparent elections, so that citizens will become active participants and stakeholders in the nation-building project.

This necessarily implies that the open, accessible and inclusive institution of the rule of law and democratic participation are urgently required in Nigeria's search for political stability and communal harmony. The subversive elite-driven politics of brigandage through coercive deployment of apparatuses of state power in the service of personal gains must be abandoned in favour of a democratic system anchored in the ethos of constitutionalism and the empowerment of the citizenry and civil society. 


\section{- REFERENCES}

Ake, C. 2003. The Feasibility of Democracy in Africa. Dakar: CODESRIA.

Adejumobi, S. 2000. 'Elections in Africa: A Fading Shadow of Democracy in Africa?'. International Political Science Review 21(1).

Agbaje, A. 2004. 'Nigeria: Prospects for the Fourth Republic'. In E Gyimah-Boadi (ed). Democratic Reform in Africa: The Quality of Progress. Boulder, CO: Lynne Rienner

Baker, B. 1997. 'Beyond the long arm of the law: The pattern and consequences of disengagement in Africa'. The Journal of Commonwealth and Comparative Politics 35(3).

Branch, D \& N Cheeseman. 2008. 'Democratization, Sequencing, and State Failure in Africa: Lessons from Kenya'. African Affairs 108(430).

Bernazzolli, R M \& C Flint. 2010. 'Embodying the garrison state? Everyday geographies of militarization in American society'. Political Geography 29.

Bratton, M \& N van de Walle. 1997. Democratic Experiments in Africa: Regime Transitions in Comparative Perspective. New York: Cambridge University Press.

Bratton, M. 2007. 'Formal versus Informal Institutions in Africa'. Journal of Democracy 18(3).

Curtis, B. 2002. 'Foucault on Governmentality and Population: The Impossible Discovery'. Canadian Journal of Sociology 27(4).

Constitution of the Federal Republic of Nigeria (as amended). 2011. Abuja: Government Printer.

Diamond, L. 1999. Developing Democracy: Toward Consolidation. Baltimore, MD: Johns Hopkins University Press.

Electoral Reform Committee. Report 2008. Vol 1: Final Report. Abuja: Government Printer.

European Union Election Observation Mission to Nigeria. 2011. Final Report 2011. Brussels: EU.

Foucault, M. 2004a. Securité, territoire, population, Cours au College de France, 19771978. Paris: Seuil/Gallimard.

Foucault, M. 2004b. Naissance de la biopolitique. Cours au College de France, 19781979. Paris: Seuil/ Gallimard.

Figueroa, M. 1994. 'Garrison Communities in Jamaica 1962-1993: Their Growth and Impact on Political Culture'. Paper presented at a conference on Democratization in Jamaica: Fifty Years of Adult Suffrage, 6-7 December, UWI Mona, Kingston, Jamaica

Figueroa, M \& A Sives. 2001. 'The Growing Impact of Jamaican Garrison Politics: Does the 1997 Election Signal a Break in the Trend'. Paper presented at the 
International Conference on Crime in the Caribbean, UWI Mona, Kingston, Jamaica.

Figueroa, M. 2002. 'Homogenous voting, electoral manipulation and "garrison" process in post-independence Jamaica'. Commomwealth and Comparative Politics 40(1).

Gyimah-Boadi, E (ed). 2004. Democratic Reform in Africa: The Quality of Progress. Boulder, CO: Lynne Rienner.

Human Rights Watch. 2007. Election or 'Selection'? Human Rights Abuse and Threats to Free and Fair Elections in Nigeria. New York: HRW.

Human Rights Watch. 2011. A Human Rights Agenda for Candidates in Nigeria's 2011 Elections. HRW Briefing Paper No 1. New York: HRW

Ihonvbere, J. 2000. Towards a New Constitutionalism in Africa. London: CDD Occasional Paper Series No 4.

Jessop, B. 2007. 'From micro-powers to governmentality: Foucault's work on statehood, state formation, statecraft and state power'. Political Geography 20.

Joseph, R. 1987. Democracy and Prebendal Politics in Nigeria: The Rise and Fall of the Second Republic. New York: Cambridge University Press.

Joseph, R. 1997. 'Democratization in Africa after 1989: Comparative and Theoretical Perspectives'. Comparative Politics 29(3).

Kendhammer, B. 2010. 'Talking ethnic but hearing multi-ethnic: the People's Democratic Party (PDP) in Nigeria and durable multi-ethnic parties in the midst of violence'. Commonwealth and Comparative Politics 48(1).

Kew, D. 2004. 'The 2003 Elections: Hardly Credible, but Acceptable'. In R I Rotberg (ed). Crafting the New Nigeria: Confronting the Challenges. Boulder, CO: Lynne Rienner.

Lemke, T. 2007. 'An Indigestible Meal? Foucault, Governmentality and State Theory'. Scandinavian Journal of Social Theory 15.

Lewis, P. 1994. 'Endgame in Nigeria: The Politics of a Failed Transition'. African Affairs 93.

Lindberg, S (ed). 2009. Democratization by Elections: A New Mode of Transition. Baltimore, MD: Johns Hopkins University Press.

Mbembe, A. 2001. On the Postcolony. Los Angeles: University of California Press.

Olukoshi, A O \& O Agbu. 1996. 'The Deepening Crisis of Nigerian Federalism and the Future of the Nation-State'. In A O Olukoshi \& L Laakso (eds). Challenges to the Nation-State in Africa. Uppsala: Nordic Africa Institute.

Omotola, J S. 2009. 'Garrison Democracy in Nigeria: The 2007 General Elections and the Prospects of Democratic Consolidation'. Commonwealth and Comparative Politics 47(2). 
Shivji, I (ed). 1991. State and Constitutionalism: An African Debate on Democracy. Harare: SAPES Trust.

Stone, C. 1980. Democracy and Clientelism in Jamaica. New Brunswick: Transaction Books.

Suberu, R. 2007. 'Nigeria's Muddled Elections'. Journal of Democracy 18(4). 